Journal of Southeast Asian

\title{
Two Poems: Chanda Says; Dropping Chanda Off at Nursery School
}

Bunkong Tuon

Union College, tuonb@union.edu

Follow this and additional works at: https://docs.lib.purdue.edu/jsaaea

Part of the Bilingual, Multilingual, and Multicultural Education Commons, and the Poetry Commons

\section{Recommended Citation}

Tuon, Bunkong (2019) "Two Poems: Chanda Says; Dropping Chanda Off at Nursery School," Journal of Southeast Asian American Education and Advancement: Vol. 14 : Iss. 1, Article 5.

DOI: $10.7771 / 2153-8999.1185$

Available at: https://docs.lib.purdue.edu/jsaaea/vol14/iss1/5

This document has been made available through Purdue e-Pubs, a service of the Purdue University Libraries. Please contact epubs@purdue.edu for additional information.

This is an Open Access journal. This means that it uses a funding model that does not charge readers or their institutions for access. Readers may freely read, download, copy, distribute, print, search, or link to the full texts of articles. This journal is covered under the CC BY-NC-ND license. 
Vol. 14 Iss. 1 (2019)

\author{
WWW.JSAAEA.org
}

\title{
Creative and Literary Works
}

\author{
Two Poems
}

Bunkong Tuon

Union College

\section{Chanda Says}

"You're the greatest daddy in the whole wide world."

Her arms wrap tightly

around my neck as she plants

A big fat juicy kiss on my cheek.

For a minute, I almost forgive

The Khmer Rouge. Then I remember my daughter would never know

Her Lok-Yiey and Lok-Ta.

\footnotetext{
(c)

SDRERIIEHISRESEREDDReaders are free to copy, display, and distribute this article, as long as the work is attributed to the author(s) and the Journal of Southeast Asian American Education \& Advancement, it is distributed for non-commercial purposes only, and no alteration or transformation is made in the work. More details of this Creative Commons license are available at http://creativecommons.org/licenses/by-nc-nd/3.0/. All other uses must be approved by the author(s) or JSAAEA. Journal of Southeast Asian American Education \& Advancement, Vol. 14. Iss. 1. (2019) ISSN: 2153-8999
} 


\section{Dropping Chanda Off at Nursery School}

Tiny legs wrap around my waist, tears streaming down her flushed cheeks, and the wailing "Daddy, Daddy, Home!" Then the door shuts behind me. I still hear her crying as I walk by the classroom window and carry her cries as I get in the car, drive to the college to teach the American/Viet Nam War. The wailing continues in the cries of soldiers missing their girlfriends, wives, and families at home, wishing to spit at their fathers who talk about doing the things men must do in a world of evils, wanting to burn their town's city hall and vandalize the draft board because no one there knows what they are going through. The wailing is heard in the little girl stripped naked by the flaming fingers of napalm as she runs with other villagers.

The wailing is felt in the trembling silence of the boy in My Lai who hides underneath the warm bodies of his aunt, younger sister, and mother. 


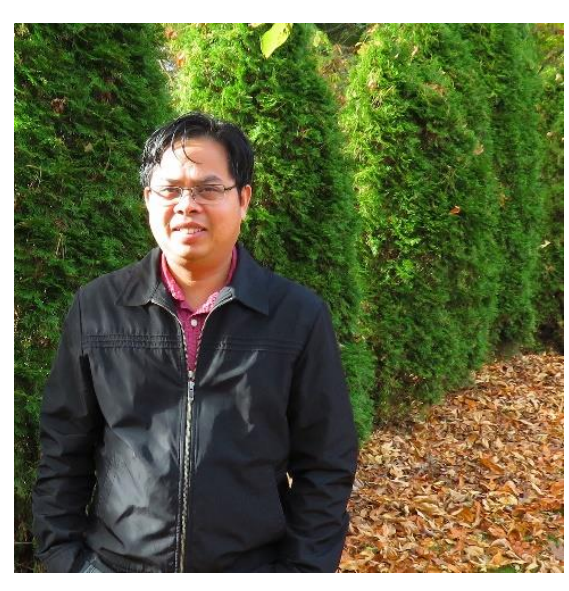

\section{About the Author}

Bunkong Tuon, a Cambodian-American writer, critic, professor, and, most importantly, father. He is the author of Gruel (New York Quarterly Books, 2015), And So I Was Blessed (New York Quarterly Books, 2017), and Dead Tongue (with Joanna C. Valente, forthcoming from Yes Poetry), as well as a contributor to Cultural Weekly. Nominated for the Pushcart numerous times, his poetry recently won the 2019 Nasiona Nonfiction Poetry Prize. He has completed a book of poems about raising his daughter in contemporary America. He is an associate professor of English and Asian Studies at Union College in Schenectady, New York. 


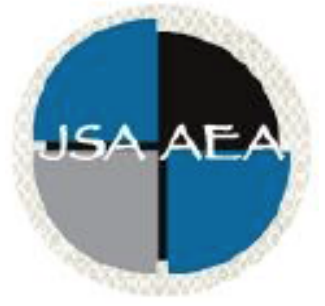

Vol.14 Iss.1 (2019)

\title{
Journal of Southeast Asian American Education and Advancement
}

\author{
WwW.JSAAEA.org
}

\section{Editor}

Dr. Wayne E. Wright

Purdue University

Associate Editors

Dr. Chhany Sak-Humphry

University of Hawaii at Manoa

Dr. Phitsamay Sychitkokhong Uy

University of Massachusetts, Lowell

\author{
Book Review Editor \\ Dr. Vichet Chhuon \\ University of Minnesota \\ Creative Works Editor \\ Bryan Thao Worra \\ Lao Assistance Center \\ Journal Manager \\ Fang Gao \\ Purdue University
}

\section{Editorial Review Board}

Dr. Steve Arounsack

California State University, Stanislaus

Dr. Sovicheth Boun

Salem State University

Dr. Virak Chan

Purdue University
Dr. Carl L. Bankston III

Tulane University

Dr. Phala Chea

Lowell Public Schools

Dr. George Chigas

University of Massachusetts, Lowell 


\author{
Dr. Loan Dao \\ University of Massachusetts Boston \\ Dr. Changming Duan \\ University of Missouri-Kansas City \\ Dr. Sothy Eng \\ Lehigh University \\ Dr. Vincent K. Her \\ University of Wisconsin, Eau Claire \\ Dr. Peter Nien-Chu Kiang \\ University of Massachusetts, Boston \\ Dr. Kevin K. Kumashiro \\ University of Illinois, Chicago \\ Dr. Ha Lam \\ Eastern Mennonite University \\ Dr. Jonathan H. X. Lee \\ San Francisco State University \\ Dr. Monirith Ly \\ Royal University of Phnom Penh \\ Dr. Bic Ngo \\ University of Minnesota \\ Dr. Leakhena Nou \\ California State University, Long Beach \\ Dr. Mark Pfeifer \\ SUNY Institute of Technology \\ Dr. Loan T. Phan \\ University of New Hampshire \\ Dr. Karen Quintiliani \\ California State University, Long Beach \\ Dr. Angela Reyes \\ Hunter College \\ The City University of New York \\ Dr. Fay Shin \\ California State University, Long Beach \\ Dr. Christine Su \\ College of San Mateo \\ Dr. Alisia Tran \\ Arizona State University \\ Dr. Khatharya Um \\ University of California, Berkeley \\ Dr. Kim Tran \\ University of California, Los Angeles, \\ Glendale Community College \\ Dr. Molly Wiebie \\ The University of Texas at Austin
}

Dr. Hien Duc Do

San Jose State University

Dr. Sophal Ear

Occidental College

Dr. Jeremy Hein

University of Wisconsin, Eau Claire

Dr. Nancy H. Hornberger

University of Pennsylvania

Dr. Peter Tan Keo

New York University

Dr. Yvonne Kwan

San Jose State University

Dr. Ravy Lao

California State University, Los Angeles

Dr. Stacey Lee

University of Wisconsin, Madison

Dr. Sue Needham

California State University, Dominguez Hills

Dr. Max Niedzwiecki

Daylight Consulting Group

Dr. Clara Park

California State University, Northridge

Dr. Giang Pham

University of Massachusetts Amherst

Dr. Malaphone Phommasa

University of Clifornia Santa Barbara

Dr. Kalyani Rai

University of Wisconsin-Milwaukee

Dr. Cathy J. Schlund-Vials

University of Connecticut, Storrs

Dr. Nancy J. Smith-Hefner

Boston University

Dr. Yer J. Thao

Portland State University

Dr. Monica M. Trieu

Purdue University

Dr. Silvy Un

Saint Paul Public Schools

Dr. Linda Trinh Vo

University of California, Irvine

Dr. Yang Sao Xiong

The University of Wisconsin-Madison

Dr. Zha Blong Xiong

University of Minnesota 


\section{Doctoral Student Editorial Review Board}

\author{
Linh Dang \\ University of Rochester \\ My-Lan Huynh \\ California State University East Bay \\ Hoa Nha Nguyen \\ Boston College \\ Thien-Huong Ninh \\ University of Southern California \\ Krissyvan Truong \\ Claremont Graduate University \\ Melissa Vang \\ San Diego State University \\ Claremont Graduate University \\ Nielsen Hul \\ Cornell University \\ Bao Diep \\ University of Minnesota
}

\author{
Annie BichLoan Duong \\ San Joaquin County Office of Education \\ Dung Minh Mao \\ University of Minnesota \\ Khoi Nguyen \\ George Mason University \\ Linda Marie Pheng \\ University of Wisconsin-Madison \\ Mai Vang \\ University of Massachusetts Boston \\ Soua Xiong \\ San Diego State University \\ Claremont Graduate University \\ Diana Chandara \\ University of Minnesota \\ Thong Vang \\ University of Minnesota
}

